\title{
The Simple Past Tense Understanding In SMA Maitreyawira Batam
}

\author{
Hidayat Polim. TESOL Department Soka University. Japan \\ E17m3252@soka-u.jp \\ Frangky Silitonga. FPTV Department Universiti Tun Hussein Onn Malaysia \\ Hb16000@siswa.uthm.edu.my \\ Mamal Zakriamal. Putera Batam University. Indonesia \\ zakrimamal@gmail.com
}

\begin{abstract}
Abstrak
Penelitian ini membahas tentang pengaruh pemahaman aspek tata bahasa (grammar) terhadap keterampilan menulis (writing skills) oleh Siswa Kelas 11 SMA Maitreyawira Batam Tahun Akademik 2012/2013. Peneliti membatasi permasalahan penelitian pada pemahaman simple past tense meliputi kata kerja beraturan (regular verb) dan tidak beraturan (irregular verb) terhadap keterampilan menulis teks narasi (narrative writing skills).Tujuan penelitian ini adalah untuk menemukan pengaruh pemahaman simple past tense terhadap keterampilan menulis dalam teks narasi. Peneliti menggunakan data kuantitatif dalam desain penelitian cross-sectional (satu waktu). Instrumen utama untuk memperoleh data ialah kuisioner tata bahasa dan keterampilan menulis yang diproses melalui aplikasi SPSS®. Hasil penelitian menunjukkan koefisien F-Hitung (124.312) bernilai lebih besar dari F-Tabel (4.043). Hal ini membuktikan bahwa terdapat pengaruh pemahaman simple past tense terhadap keterampilan dalam menulis teks narasi. Lebih lanjut, hasil pengolahan data menunjukkan nilai $R$-square yaitu 84.1\%. Nilai ini menggambarkan bahwa pengaruh pemahaman simple past tense terhadap keterampilan menulis teks narasi adalah dominan.
\end{abstract}

Kata Kunci: Grammar, Simple Past Tense, Regular Verb, Irregular Verb, Writing Skills, Narrative Writing Skills

\section{INTRODUCTION}

English language is one of the unique languages. There are many aspects that have to be mastered in order to communicate in English well. They are ability in listening, reading, speaking and exactly writing which relates each other in daily communication. In the case of learning, writing skills are among the most complex and difficult subject by most learners. Writing itself is the symbolic representation of language in storable graphic form; it is a comparatively recent cultural development, having occurred within the past five thousand years and only in certain parts of the world (O’Grady et al, 1997: 591). Therefore, as a recent cultural development, the skills in writing have to be concerned as an important thing in the language learning. In the term of language skills, writing skills are specific abilities which help writers put their thoughts into words in a meaningful form and to mentally interact with the message (www.sil.org). This means that if learner wanted to conduct communication through writing, she or he has to know and master the skills of writing itself. However, there are still many students of English who get difficulties in having a good writing because of their weakness in writing skills. This matter does not seem strange because as a complex skill in learning a language, writing has varieties of 
aspects to be concerned in order to be judged as a good writing. These elements include mechanics, vocabulary, grammar, diction, coherence, cohesion and so on (Madsen, 1983:101). Here, the researcher focuses on one of the grammar aspect i.e. tenses, specifically simple past tense which describes the situation happened in the past or prior moments. In writing, this tense is commonly used in the form of narrative or recount text (Sudarwati \& Grace, 2007: 74). According to Hewings \& Hewings (2005:12), it is generally accepted that an understanding of the grammar will improve well-formed language includes in the writing form. Thus, the grammatical understanding of this tense finally will affect the ability of student in having a good and comprehensive writing. Therefore, the researcher conducted a research entitled "The Influences of Simple Past Tense Understanding towards Writing Skills by $11^{\text {th }}$ Grade Students of SMA Maitreyawira Batam in Academic Year 2012/2013.”

Through the investigation of interviewing the teacher of $11^{\text {th }}$ Grade Students of SMA Maitreyawira Batam, the researcher found that most students were getting difficulties in the writing skills aspects i.e. the use of simple past tense. These were shown by the student's answer in the textbook, for the following questions:

Change the verbs in brackets into the correct past form!

One day, the people of Benerawa (6. go)....... hunting. They (7. find)..... a big snake and cut it into pieces. (Sudarwati \& Grace, 2007: 127)

In the questions above, the researcher found through the text book, some students answered 'goes' for item number six (6) and 'finds' for item number seven (7). These showed that the use of tenses were incorrect. Most of the students knew that they had to use simple past tense, but they did not really know the use of regular and irregular verb as indicators of simple past tense. Therefore, the researcher had found the significant problem regarding the use of regular and irregular verb as the simple past tense indicators and its implementation as writing skills in narrative text.

Afterwards, the researcher has figured out some limitations of the research included: 1) The influence of regular verb understanding towards narrative writing skills by $11^{\text {th }}$ Grade Students of SMA Maitreyawira Batam in academic year 2012/2013, 2) The influence of irregular verb understanding towards narrative writing skills by $11^{\text {th }}$ Grade Students of SMA Maitreyawira Batam in academic year 2012/2013, 3) The influence of simple past tense understanding towards narrative writing skills by $11^{\text {th }}$ Grade Students of SMA Maitreyawira Batam in academic year 2012/2013 and 4) The extent on the influences of simple past tense understanding towards narrative writing skills by $11^{\text {th }}$ Grade Students of SMA Maitreyawira Batam in academic year 2012/2013.

Therefore, the objectives of the research were to 1) To find out the influence of regular verb understanding towards narrative writing skills by $11^{\text {th }}$ Grade Students of SMA Maitreyawira Batam in academic year 2012/2013, 2) To find out the influence of irregular verb understanding towards narrative writing skills by $11^{\text {th }}$ Grade Students of SMA Maitreyawira Batam in academic year 2012/2013, 3) To find out the influence of simple past tense understanding towards narrative writing skills by $11^{\text {th }}$ Grade Students of 
SMA Maitreyawira Batam in academic year 2012/2013, and 4) To find out to what extent the influences of simple past tense understanding towards narrative writing skills by $11^{\text {th }}$ Grade Students of SMA Maitreyawira Batam in academic year 2012/2013.

Figure 1 Theoretical Framework of the Research

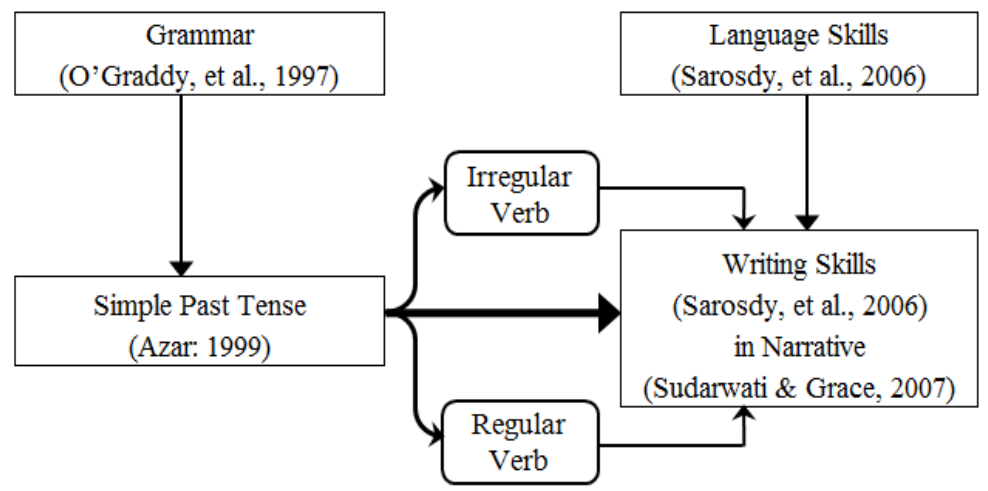

The researcher defined two research variables of Simple Past Tense as one of Grammatical aspect in language and Writing Skills as the part Language skills. All of the variables of this research were connected by arrows, which showed the relationship of the independent variables towards the dependent variables.

\section{REVIEW OF RELATED LITERATURE} AND HYPOTHESIS

Grammar includes a wide range of topics as well as tenses. According to Jarvie (2007: 32), the word tense is from Latin tempus, 'time', and it is used to show the time when the action of a verb takes place. There are many kinds of tense in English. However, basically the forms come from the first three basic tenses of present, past and future tense. Here, the researcher is going to discuss the part of tenses known as simple past tense.

\section{Simple Past Tense}

Simple past tense indicates that an activity or situation began and ended at a particular time in the past (Azar, 1999: 27). The formula in composing sentences in simple past, both for Verb and Non-verb were as follows:

Table 1

Formula of Simple Past Tense

\begin{tabular}{|l|l|l|l|}
\hline \multicolumn{1}{|c|}{ Form } & \multicolumn{1}{|c|}{ Pattern with Verb } & \multicolumn{1}{c|}{ Form } & \multicolumn{1}{c|}{ Pattern with Non-Verb } \\
\hline Affirmative & $\begin{array}{l}\text { S + V2 + Object } \\
\text { e.g.: -I went to the book store } \\
\text { yesterday. } \\
\text {-They played football last } \\
\text { Sunday. }\end{array}$ & Affirmative & $\begin{array}{l}\text { S + was/ were + Non-Verb } \\
\text { e.g.: -I was ill yesterday. } \\
\text {-They were happy last night. }\end{array}$ \\
\hline Negative & S + did + not + V1 + Object & Negative & S + was/were + not + Non-Verb \\
\hline
\end{tabular}




\begin{tabular}{|l|l|l|l|}
\hline & $\begin{array}{l}\text { e.g.: -Maya didn't come to the } \\
\text { party. } \\
\text {-He didn't pay his phone } \\
\text { bill. }\end{array}$ & & $\begin{array}{l}\text { e.g.: -I was not ill yesterday. } \\
\text {-They were not happy last night. }\end{array}$ \\
\hline Interrogative & $\begin{array}{l}\text { Did/didn't + S + V1 + Interrogative } \\
\text { Object } \\
\text { e.g.: -Did you meet him last } \\
\text { night? } \\
- \text {-Didn't they tell you } \\
\text { about it? }\end{array}$ & $\begin{array}{l}\text { Was/Were + S + Non-Verb? } \\
\text { e.g.: -Was he ill yesterday? } \\
\text {-Were they happy last night? } \\
\text { (Serious English for Serious Student, } \\
\text { 2006: 184-185) }\end{array}$ \\
\hline
\end{tabular}

\section{Regular Verb}

Based on Huddleston \& Pullum (2007: 268), regular verb includes unlimited number of regular verb compared with only a limited number of special exceptional ones about 200 irregular verb forms. Regular verb is formed by adding $-d$ or $-e d$ as described by Jarvie
(2007:36). According to official site of University of Victoria, regular verb is mostly created simply by adding -ed. However, with some verbs, there is a need to add $-d$ or change the ending a little. The rules were shown by the following table:
Irregular Verb

\begin{tabular}{|c|c|c|}
\hline Verb ending in... & How to make the simple past & Examples \\
\hline$e$ & Add $-d$ & $\begin{array}{l}\text { live } \rightarrow \text { lived } \\
\text { date } \rightarrow \text { dated }\end{array}$ \\
\hline Consonant ty & Change $y$ to $i$, then add $-6 d$ & $\begin{array}{l}\text { try } \rightarrow \text { tried } \\
\text { cry } \rightarrow \text { cried }\end{array}$ \\
\hline $\begin{array}{l}\text { One vowel t one } \\
\text { cons onant } \\
\text { (but NOT } w \text { or } y \text { ) }\end{array}$ & $\begin{array}{l}\text { Double the cons onant, then add- } \\
\text { od }\end{array}$ & $\begin{array}{l}\text { tap } \rightarrow \text { tapped } \\
\text { commit } \rightarrow \text { committed }\end{array}$ \\
\hline anything else inchuding $w$ & Add-ED & $\begin{array}{l}\text { boil } \rightarrow \text { boiled } \\
\text { show } \rightarrow \text { showed }\end{array}$ \\
\hline
\end{tabular}

\section{Irregular Verb}

It forms the past differently without any $-d$ or $-e d$ form. For example, the past form of the verb "break" is "broke" and the past participle is "broken." According to Huddleston
\& Pullum (2007: 274-275), irregular verb can be formed in many different patterns as described below: 
Table 3

Irregular Verb Form

\begin{tabular}{|c|c|c|c|}
\hline Form & Present & Past & Description \\
\hline $\mathbf{a}$ & Hit & Hit & $\begin{array}{l}\text { Most of them have bases ending in } t \text {, but there are also a few } \\
\text { in } d \text {, such as shed }\end{array}$ \\
\hline $\mathbf{b}$ & Bend & Bent & $\begin{array}{l}\text { It differs simply in the replacement of final d by t. They } \\
\text { include build, send, spend, and so on. }\end{array}$ \\
\hline c & Bum & Bumt & $\begin{array}{l}\text { Bases ending in }-l l \text { lose one }-l \text { before }-t \text {, e.g. smell - smelt. } \\
\text { Other examples include dwell, learn, spoil. }\end{array}$ \\
\hline d & Keep & Kept & $\begin{array}{l}\text { It includes the addition of }-t \text { which is accomparied by } \\
\text { modification of the base. Other members of the class include } \\
\text { feel, mean, sleep. }\end{array}$ \\
\hline e & Flee & Fled & $\begin{array}{l}\text { The verbs add }-d \text { rather than }-t \text {, with modification of the } \\
\text { base. Others include hear, say, sell. }\end{array}$ \\
\hline f & Think & Thought & $\begin{array}{l}\text { Irregular past form with -ought or -aught. It is formed by } \\
\text { replacing vowel + any following consonants in the base. The } \\
\text { examples are buy, catch, seek, etc. }\end{array}$ \\
\hline g & Dig & Dug & $\begin{array}{l}\text { It differs from the base just in respect of the vowel. A variety } \\
\text { of different vowel pairs are found: compare hang-hung, find } \\
\text { - found, shine-shone, etc }\end{array}$ \\
\hline $\mathbf{h}$ & Stand & Stood & $\begin{array}{l}\text { The verb has a unique difference between past form and base } \\
\text { form. The other examples are had and made which differ } \\
\text { from have and make in the second consonant. }\end{array}$ \\
\hline
\end{tabular}

\section{Writing Skills}

There are some skills that compose part of language used in the communication, include reading, listening, speaking and writing skills (Sarosdy et al., 2006: 51). According to linguists, O'Graddy, et.al, writing is the symbolic representation of language in storable graphic form; it is a comparatively recent cultural development, having occurred within the past five thousand years and only in certain parts of the world (1997: 591). Writing skills which grouped as productive skills consist of some important skills that have to be mastered. Those skills are described here by Edge (1999: 116), as follows: 1) The ability to develop meanings logically and clearly, 2) The ability to express unambiguously the function of what you say or write, 3) The ability to use language appropriate for the people you are addressing.

\section{Narrative Writing Skills}

Narrative text has some purposes, i.e.: to amuse or entertain, to deal with actual or imaginative experiences in different ways
(Sudarwati \& Grace, 2007: 74). There are at least three parts within narrative text: 1) Orientation is an introduction of the narrative text. It introduces the characters of the story, the time and place the story happened. Specifically, this part concerns on who or what, when, and where the story happened, 2) Complication is about the series of events in which the main character attempts to solve the problem. This is the middle part where problem of the story raise to the peak. 3) Resolution is the ending of a story (Sudarwati \& Grace, 2007: 52 \& 74).

The aspect of writing skills includes some major sub-skills like spelling, punctuation, orthography, writing at the required speed, linguistics competence, cohesion, style and so on (Sarosdy, et al, 2006: 60-61). In narrative writing, there are special features used in the text. According to Sudarwarti \& Grace (2007: 74), the features are described as follows: 1) Focus on specific and individualized participants, 2) The use of material process (action verb), 3) The use of some behavioral and 
verbal processes, 4) The use of relational and mental processes, 5) The use of past tenses, 6) The use of temporal conjunctions and circumstances.

As found by the researcher in the $11^{\text {th }}$ Grade of SMA Maitreyawira Batam, the forms of narrative texts are all simple and brief around half-page until one-page only for each text. This helps the students in getting a good comprehension regarding the text. Besides, the vocabularies used are also common words. The students studied the common types of narrative like fables, horror, history story as well as old legend. They learnt on the grammatical aspects of those narrative texts include conjunction, relative clause, adverb and past tense. They had several kinds of tasks such as labeling parts of narrative text, filling in the blanks with vocabularies including changing verb into the past form.

Past tense is used due to the time of action in narrative that is in the past. Furthermore, there are also mental processes which represent the coherence and cohesion in narrative writing. According to Young-Min (2012), coherence means the connection of ideas at the idea level, and cohesion means the connection of ideas at the sentence level.

\section{Hypothesis}

The researcher had taken three hypotheses regarding the framework of the research include 1) regular verb, 2) irregular verb and 3) simple past tense towards narrative writing skills. These divided into both Null Hypothesis $\left(\mathrm{H}_{0}\right)$ and Alternative Hypothesis $\left(\mathrm{H}_{1}\right)$, as follow: 1) $\mathrm{H}_{0}=$ there is no influence of regular verb understanding towards narrative writing skills or $\mathrm{H}_{1}=$ there is influence of regular verb understanding towards narrative writing skills, 2) $\mathrm{H}_{0}=$ there is no influence of irregular verb understanding towards narrative writing skills or $\mathrm{H}_{1}=$ there is influence of irregular verb understanding towards narrative writing skills, 3) $\mathrm{H}_{0}=$ there is no influence of simple past tense understanding towards narrative writing skills or $\mathrm{H}_{1}=$ there is influence of simple past tense understanding towards narrative writing skills.

\section{METHODOLOGY OF THE RESEARCH}

The researcher used quantitative research as the base for the research processing. Quantitative research is an approach to research that aims at causal explanation of phenomena through the identification of variables which can be made the basis of experimental investigation (Richards and Schmidt, 2010: 476). It meant that the research focused on only the data for specific or particular time and at particular place. The style used in this research was called Cross Sectional study. According to Cohen et al. (2007:213), this term means a study which produces a 'snapshot' of a population at particular point in time. The research conducted this research in the specific time that had been scheduled by the researcher and the institution where the research taken place. This consideration was also related to the short period of research given in conducted this research.

The Simple Past Tense (X) variable consisted of two sub variables of Regular Verb (X1) and Irregular Verb (X2) and Writing Skills (Y), as shown in the following diagram: 
Figure 2 Research Design

Independent Variables

Dependent Variable

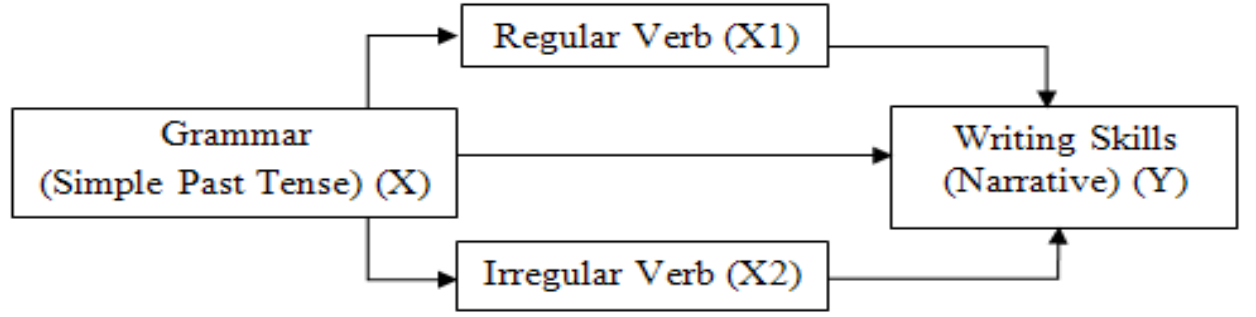

\section{Population and Sample}

According to Sahai \& Khurshid (2001: 203 \& 236), population is a complete set of objects, measurements, or individuals sharing some common observable characteristic of interest and sample is a subset or a portion of the entire aggregate of a population. This meant that, in order to get the number of population and sample in conducting the research, there must be a clear and exact data to be taken. The population was taken from the $11^{\text {th }}$ Grade Students of SMA Maitreyawira Batam in Academic Year of 2012/2013 amounted 57 (fifty-seven) students.

Table 4

Population of $11^{\text {th }}$ Grade Students

\begin{tabular}{|c|c|c|c|c|}
\hline \multirow{2}{*}{$\begin{array}{c}\text { Number of } \\
\text { Students }\end{array}$} & $\begin{array}{c}|c| \\
\text { Class Program } \\
\text { class }\end{array}$ & $\begin{array}{c}11 \text { th } \\
\text { Social } \\
\text { class I }\end{array}$ & $\begin{array}{c}\text { 11th Social } \\
\text { class II }\end{array}$ & $\begin{array}{c}\text { Total Number of } \\
\text { Population }\end{array}$ \\
\hline Female & 10 & 10 & 8 & $\mathbf{2 8}$ \\
\hline Male & 9 & 10 & 10 & $\mathbf{2 9}$ \\
\hline Total & $\mathbf{1 9}$ & $\mathbf{2 0}$ & $\mathbf{1 8}$ & $\mathbf{5 7}$ \\
\hline
\end{tabular}

In order to take exact number of sample from the total population, the researcher used statistical method formulated by Slovin, as in the description below:

Formula Slovin's

$$
\boldsymbol{n}=\frac{\boldsymbol{N}}{\mathbf{1 + N \boldsymbol { e } ^ { \mathbf { 2 } }}} \quad \begin{array}{ll}
\mathrm{n} & \text { : Number of sample } \\
\mathrm{N} & \text { : Total number of population } \\
\text { (Rumengan, 2010: } 151)
\end{array}
$$

The total number of sample (n) was taken from the total number of (population $(\mathrm{N})$ that is 57 students divided by the sum of $1+57 \times(0.05)^{2}$ resulted the exact number of 49.9 samples. In order to get an easier and reasonable point, these numbers were rounded off to the exact of 50 samples.

\section{Technique and Instrument of Collecting Data}

The researcher used interview and questionnaire. Interview was used in getting the secondary data of general information regarding the school and questionnaire was used in gaining the primary data from respondents. In collecting the data, there were 6 (six) stages from the first stage of interviewing the teacher, delivering proposal for conducting research at the school institution, getting the agreement for conducting the research, confirming schedule of the questionnaire and delivering the questionnaire. Finally, it reached the final stage of collecting questionnaire result. 
Table 5

Stage of Collecting Questionnaire

\begin{tabular}{|c|c|c|c|}
\hline Activity & Date & Place & Remark \\
\hline $\begin{array}{l}\text { 1. Interviewing the } \\
\text { English Teacher }\end{array}$ & 11 Oct 2012 & $\begin{array}{l}\text { SMA Maitreyawira } \\
\text { Batam }\end{array}$ & $\begin{array}{l}\text { Asking about the current problem } \\
\text { of the variables faced by students } \\
\text { and collecting student's text book. }\end{array}$ \\
\hline $\begin{array}{l}\text { 2. } \\
\text { Delivering } \\
\text { Proposal for the } \\
\text { research }\end{array}$ & 13 Dec 2012 & $\begin{array}{l}\text { SMA Maitreyawira } \\
\text { Batam }\end{array}$ & $\begin{array}{l}\text { Asking permission from the } \\
\text { principle. }\end{array}$ \\
\hline $\begin{array}{l}\text { 3. Accepting } \\
\text { agreement from } \\
\text { the School }\end{array}$ & 18 Dec 2012 & $\begin{array}{l}\text { SMA Maitreyawira } \\
\text { Batam }\end{array}$ & $\begin{array}{l}\text { Getting the agreement letter } \\
\text { regarding the research. }\end{array}$ \\
\hline $\begin{array}{l}\text { 4. } \text { Confirming } \\
\text { Questionnaire } \\
\text { schedule }\end{array}$ & 21 Dec 2012 & $\begin{array}{l}\text { SMA Maitreyawira } \\
\text { Batam }\end{array}$ & $\begin{array}{l}\text { Scheduling the questionnaire } \\
\text { through the teacher. }\end{array}$ \\
\hline Activity & Date & Place & Remark \\
\hline $\begin{array}{l}\text { 5. Questionnaire } \\
\text { held }\end{array}$ & 4 Jan 2013 & $\begin{array}{l}\text { SMA Maitreyawira } \\
\text { Batam }\end{array}$ & $\begin{array}{l}\text { Conducting the questionnaire for } \\
35 \text { minutes. }\end{array}$ \\
\hline $\begin{array}{ll}\text { 6. } & \text { Collecting } \\
& \text { questionnaire } \\
& \text { result } \\
\end{array}$ & 4 Jan 2013 & $\begin{array}{l}\text { SMA Maitreyawira } \\
\text { Batam }\end{array}$ & $\begin{array}{l}\text { Taking the filled questionnaire } \\
\text { from the students. }\end{array}$ \\
\hline
\end{tabular}

\section{Interview}

Through interviewing the teacher, the researcher found the data on number of students in $11^{\text {th }}$ Grade of SMA Maitreyawira Batam. Afterwards, the researcher gathered information and found relevant references of research variables through text-book. The data came from the current text-book used in the English class i.e.: Look Ahead Book 2 an English Course for Senior High School Students Year XI written by Sudarwati and Grace.

Table 6

Matrix of Interview

\begin{tabular}{|l|l|l|l|}
\hline No. & Topic & \multicolumn{1}{|c|}{ Sub-topic } & \multicolumn{1}{|c|}{ No. of Questions } \\
\hline \multirow{2}{*}{1} & \multirow{2}{*}{ Student's data } & Number of student & 1 \\
\cline { 3 - 5 } & & Current condition of the students' learning in English & 2 \\
\hline 2 & Student's book & Textbook used in class & 1 \\
\hline
\end{tabular}

\section{Questionnaire}

Questionnaires are frequently used to measure people's attitudes to and perception of languages (Litosselliti, 2010: 60). Questionnaire was used in this research as a part in getting both the general information and some data of the 
respondent in the case of their habits in using English as well as in getting data for dependent and independent variables. Therefore, the researcher had divided the questionnaire into three parts of respondent's data, questionnaire on grammar and questionnaire on writing skills. Respondent's data questionnaire included age, gender, area of using English, frequency of using English weekly, taking English course, length in English course and preferable aspect in English. On the other hand, questionnaire on grammar and writing skills used the Likert's scale response provided by Vagias (2006) as shown below:

Table 7

Likert's Scales Response

\begin{tabular}{|c|c|}
\hline \multicolumn{2}{|c|}{ Level of Difficulty } \\
\hline Description & Scale \\
\hline Very Difficult & 1 \\
\hline Difficult & 2 \\
\hline Easy & 3 \\
\hline Very Easy & 4 \\
\hline
\end{tabular}

The matrix of the questionnaires in writing skills and grammar included 12 questions for each narrative writing skills and simple past tense variables, as in the following table:

Table 8

Questionnaires on Writing Skills and Simple Past Tense

\begin{tabular}{|c|c|c|c|}
\hline Variable & Indicators & $\begin{array}{l}\text { No. of } \\
\text { Item }\end{array}$ & No. of Item in the Questionnaire \\
\hline \multirow{4}{*}{ Writing Skills } & Grammar: & \multirow{2}{*}{10} & \multirow{2}{*}{$1,2,3,4,5,6,7,8,9,10$} \\
\hline & Simple past tense & & \\
\hline & Cohesion \& & \multirow{2}{*}{2} & \multirow{2}{*}{9,10} \\
\hline & Coherence & & \\
\hline \multicolumn{2}{|c|}{ Total } & 12 & 12 \\
\hline \multirow{2}{*}{ Simple Past Tense } & Regular verb & 6 & $2,5,7,8,10,12$ \\
\hline & Irregular verb & 6 & $1,3,4,6,9,11$ \\
\hline \multicolumn{2}{|c|}{ Total } & 12 & 12 \\
\hline
\end{tabular}




\section{FINDING AND DISCUSSION}

In analyzing the quantitative data, the researcher used SPSS version 20 as a tool in giving accurate and efficient statistical calculation. The program of SPSS 20 (Statistical

\section{Description of Respondent}

Age

Table 9

Age Frequency

\begin{tabular}{|c|c|c|c|}
\hline & & Frequency & Percent \\
\hline & 15 & 4 & 8.0 \\
\hline & 16 & 33 & 66.0 \\
\hline Valid & 17 & 11 & 22.0 \\
\hline & 18 & 2 & 4.0 \\
\hline & Total & 50 & 100.0 \\
\hline
\end{tabular}

From the above table, it showed that the ranges of ages were fifteen, sixteen, seventeen
Package for the Social Sciences) is a data management and statistical analysis program that has been specifically designed for applications in the social sciences.

\section{Gender}

Table 10

Gender Frequency

\begin{tabular}{|rl|r|r|}
\hline & & Frequency & \multicolumn{1}{c|}{ Percent } \\
\hline \multirow{4}{*}{ Valid } & Male & 26 & $\mathbf{5 2 . 0}$ \\
& Female & 24 & $\mathbf{4 8 . 0}$ \\
& Total & 50 & 100.0 \\
\hline
\end{tabular}

The table shows that $52 \%$ represented number of respondents who are male and the remaining of $48 \%$ is female. 
Table 11

The Frequency Area of Using English

\begin{tabular}{|rl|r|r|}
\hline & & Frequency & Percent \\
\hline \multirow{2}{*}{ Valid } & at Home & 1 & $\mathbf{2 . 0}$ \\
& at School & 39 & $\mathbf{7 8 . 0}$ \\
& Everywhere & 10 & $\mathbf{2 0 . 0}$ \\
& Total & 50 & 100.0 \\
\hline
\end{tabular}

It showed that $78 \%$ of the total showed the habit of $11^{\text {th }}$ grade students of SMA respondents use English at school. This statistic Maitreyawira in using English.

\section{Frequency of Using English Weekly}

Table 12

The Frequency of Using English Weekly

\begin{tabular}{|c|c|c|c|}
\hline & & Frequency & Percent \\
\hline \multirow{6}{*}{ Valid } & Never & 8 & 16.0 \\
\hline & Almost never & 9 & 18.0 \\
\hline & Sometimes & 29 & 58.0 \\
\hline & Often & 3 & 6.0 \\
\hline & Very often & 1 & 2.0 \\
\hline & Total & 50 & 100.0 \\
\hline
\end{tabular}

The frequency of using English weekly by $11^{\text {th }}$ grade students of SMA Maitreyawira Batam is shown by the table. Here, there are five options for choosing the level of frequency in using English. However, it shows most of the respondents (58\%) sometimes use English.

\section{Taking English Course}

Table 13

The Frequency of Taking English Course

\begin{tabular}{|rl|r|r|}
\hline & & Frequency & \multicolumn{1}{|c|}{ Percent } \\
\hline \multirow{3}{*}{ Valid } & No & 32 & $\mathbf{6 4 . 0}$ \\
& Yes & 18 & $\mathbf{3 6 . 0}$ \\
& Total & 50 & 100.0 \\
\hline
\end{tabular}


This showed the number of students who had taken part in advancing their English outside the formal education at school. It gave information that more than half of the students (64\%) were not having any English course.

\section{Length in Taking English Course}

Table 14

The Frequency of Length in Taking English Course

\begin{tabular}{|c|c|c|c|}
\hline & & Frequency & Percent \\
\hline \multirow{6}{*}{ Valid } & Never & 32 & 64.0 \\
\hline & $<6$ months & 5 & 10.0 \\
\hline & 1 years & 5 & 10.0 \\
\hline & 2 years & 3 & 6.0 \\
\hline & $>3$ years & 5 & 10.0 \\
\hline & Total & 50 & 100.0 \\
\hline
\end{tabular}

The percentages of length in taking English course were all $10 \%$ for the six months, one year and more than three years, while it was $6 \%$ for them who had taken course for two years.

\section{Preferable Aspect of English}

Table 15

The Frequency of Preferable Aspect of English

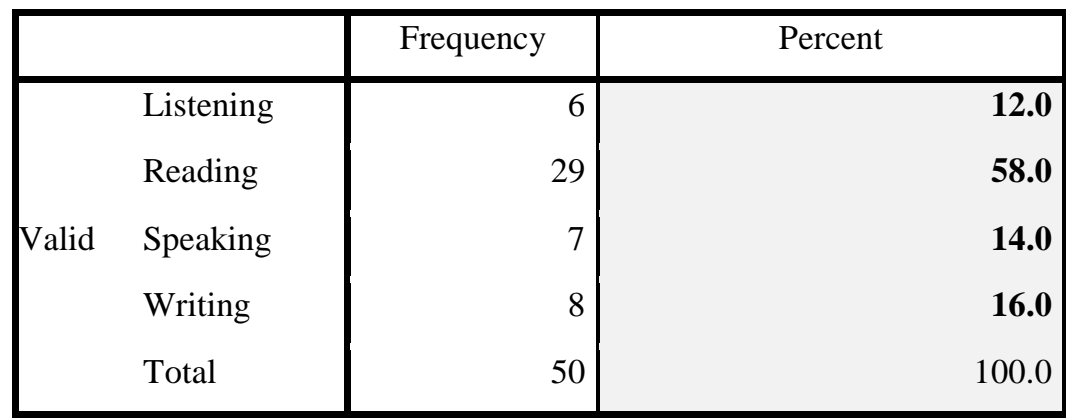

From the table, it showed that most of the respondents $(58 \%)$ were interested in reading more than the others.

\section{Validity of Instrument}

In determining whether the item of instruments; questionnaire was valid, the researcher referred to Azwar in Wibowo's
(2012: 36) who stated that as if an item has a minimum correlation-coefficient of Pearson's at 0.30 , the item could be thought as valid item 
Table 16

Pearson Correlation Coefficients

\begin{tabular}{|c|c|c|c|c|c|c|c|c|c|c|c|c|}
\hline $\begin{array}{c}\text { Pearson } \\
\text { Correlation } \\
\text { Coefficient }\end{array}$ & \multicolumn{10}{|c|}{ Item } \\
\hline Regular Verb & 0.913 & 0.827 & 0.942 & 0.946 & 0.939 & 0.933 & & & & & & \\
\hline Irregular Verb & 0.881 & 0.79 & 0.888 & 0.865 & 0.836 & 0.871 & & & & & & \\
\hline $\begin{array}{l}\text { Narrative } \\
\text { Writing Skills }\end{array}$ & 0.87 & 0.881 & 0.847 & 0.889 & 0.851 & 0.864 & 0.889 & 0.819 & 0.796 & 0.84 & 0.815 & 0.772 \\
\hline
\end{tabular}

coefficients of Pearson's correlation at 0.30 , all the items of regular verb, irregular verb and also narrative writing skills had shown higher coefficients than the minimum standard stated by Azwar. Thus, the items were valid to be used in this research.

\section{Reliability of Instrument}

Table 17

Cronbach's Alpha Coefficients

\begin{tabular}{|l|r|r|}
\hline \multicolumn{1}{|c|}{ Variable } & $\begin{array}{r}\text { Cronbach's } \\
\text { Alpha } \\
\text { Coefficient }\end{array}$ & $\begin{array}{r}\text { N of } \\
\text { Items }\end{array}$ \\
\hline Regular Verb & $\mathbf{0 . 9 6 1}$ & 6 \\
\hline Irregular Verb & $\mathbf{0 . 9 2 4}$ & 6 \\
\hline $\begin{array}{l}\text { Narrative Writing } \\
\text { Skills }\end{array}$ & $\mathbf{0 . 9 6 3}$ & 12 \\
\hline
\end{tabular}

The above table showed the Cronbach's alpha coefficient of each variable. All of the variables had a coefficient which is higher than 0.80 as a standard stated by Jackson. Therefore, the questionnaires were reliable to be used in this research.

\section{Hypothesis Testing}

\section{T-Test}

reliability refers to the consistency or stability of a measuring instrument. She stated that in establishing a measure which is reliable, it needs a positive correlation coefficient of around 0.80 or higher (Jackson, 2010:83). The table of Cronbach's alpha coefficient used for showing the reliability of each variable was as follows:

The researcher used the T-Test in order to prove the first hypothesis (regular verb) and second hypothesis (regular verb). The questionnaires data were calculated through SPSS 20 and results the Coefficients table for Ttest, as follows: 
Table 18

Coefficients for T-Test

\begin{tabular}{|c|c|c|c|c|c|c|}
\hline & \multirow{2}{*}{ Model } & \multicolumn{2}{|c|}{$\begin{array}{l}\text { Unstandardized } \\
\text { Coefficients }\end{array}$} & $\begin{array}{l}\text { Standardized } \\
\text { Coefficients }\end{array}$ & \multirow{2}{*}{$\mathbf{t}$} & \multirow{2}{*}{ Sig. } \\
\hline & & B & $\begin{array}{l}\text { Std. } \\
\text { Error }\end{array}$ & Beta & & \\
\hline \multirow{3}{*}{1} & (Constant) & 2.345 & 2.484 & & .944 & .350 \\
\hline & Total_Regular_Verb & -.049 & .314 & -.023 & -.157 & .876 \\
\hline & Total_Irregular_verb & 1.934 & .306 & .938 & 6.313 & .000 \\
\hline
\end{tabular}

a. Dependent Variable: Total_Writing

The criteria for T-Test were as follows:

a. If T-test $>\mathrm{T}$-table, $\mathrm{H}_{0}$ is rejected; $\mathrm{H}_{1}$ is accepted

b. If T-test $<\mathrm{T}$-table, $\mathrm{H}_{0}$ is accepted; $\mathrm{H}_{1}$ is rejected (Wibowo, 2012: 133)

The value of T-Test was compared to the T-Table i.e. 2.011. From the above table, the coefficient of T-test for regular verb was -0.157 . This value was less than the T-table (2.011). Therefore, the decision taken for the first hypothesis was $\mathrm{T}$-test $<\mathrm{T}$-table, $\mathrm{H}_{0}$ was accepted; $\mathrm{H}_{1}$ was rejected. Then, the coefficient of T-test for irregular verb was 6.313. This value was bigger than the T-table (2.011). Therefore, the decision taken for the second hypothesis was T-Test > T-Table, $\mathrm{H}_{0}$ was rejected; $\mathrm{H}_{1}$ was accepted.

\section{F-Test}

Furthermore, the researcher used F-Test in proving the third hypothesis. The value of FTest was shown by ANOVA table as follows:

Table 19

ANOVA for F-Test

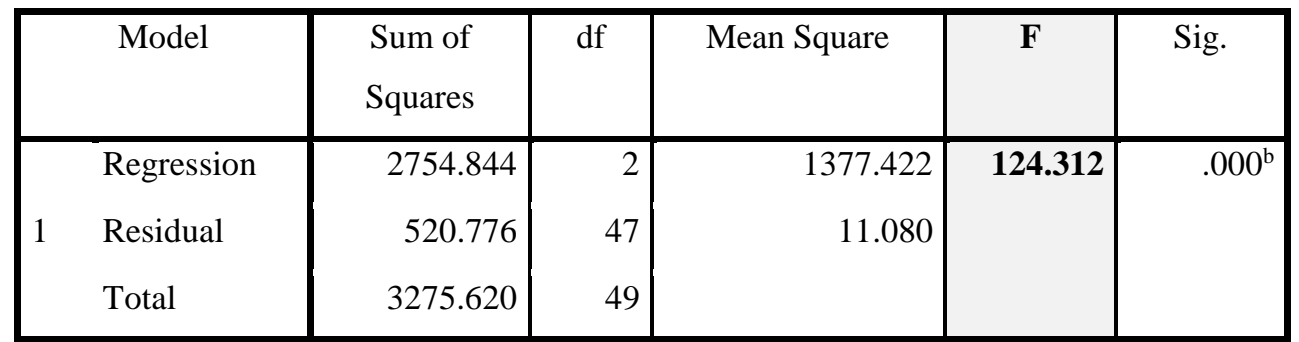

a. Dependent Variable: Total_Writing

b. Predictors: (Constant), Total_Irregular_verb, Total_Regular_Verb

The criteria for the F-Test were as follows:

a. If F-Test > F-Table, $\mathrm{H}_{1}$ is accepted; $\mathrm{H}_{0}$ is rejected b. If F-Test < F-Table, $\mathrm{H}_{1}$ is rejected; $\mathrm{H}_{0}$ is accepted (Wibowo, 2012: 133)

The value of F-Test was compared to the F-Table of the appropriate samples of this research. Based on the F-Table, the F-table 
coefficient of this research was 4.043. From the ANOVA table above, the F-Test coefficient was 124.312. It was greater than the F-table 4.043. Therefore, due to the criteria of F-Test, the criterion for the third hypothesis was F-Test $>$ FTable, $\mathrm{H}_{1}$ was accepted; $\mathrm{H}_{0}$ was rejected.

In order to answer the last point in objectives of the research i.e. to find out to what extent the influences of simple past tense understanding towards writing skills, the researcher had calculated the $\mathrm{R}$ square $\left(\mathrm{R}^{2}\right)$ of both independent variables as a method in giving appropriate interpretation. The $\mathrm{R}$ square showed the extent of influences that independent variables had on the dependant variable. The output of for R square was as follows:

Table 20

Model Summary for R Square

\begin{tabular}{|l|c|r|r|c|}
\hline Model & $\mathrm{R}$ & R Square & $\begin{array}{c}\text { Adjusted R } \\
\text { Square }\end{array}$ & $\begin{array}{c}\text { Std. Error of the } \\
\text { Estimate }\end{array}$ \\
\hline 1 & $.917^{\mathrm{a}}$ & $\mathbf{. 8 4 1}$ & .834 & 3.32871 \\
\hline
\end{tabular}

a. Predictors: (Constant), Total_Irregular_verb,

Total_Regular_Verb

b. Dependent Variable: Total_Writing

The above table showed the $\mathrm{R}$ square $\left(\mathrm{R}^{2}\right)$ if both regular and irregular verb were calculated in the regression analysis towards narrative writing skills i.e. $0.841(84.1 \%)$. This meant that regular verb and irregular verb (simple past tense) influence $84.1 \%$ on narrative writing skills variable. Then, the remaining $15.9 \%$ is influenced by the other aspects which were not researched. This result proved the argument proposed by Hewings \& Hewings, who stated that it is generally accepted that an understanding of the grammar of language can help in constructing well-formed language such as in writing (2005:12).

The researcher emphasized that the understanding of simple past tense is important in having a good writing skills, especially in narrative text. Related to the respondents i.e. $11^{\text {th }}$ Grade Students, their understanding in grammar like in simple past tense would enable them to have better skills in aspects of writing. This was crucial because most of the lesson learnt by the students were closely related to the topic of writing and grammar. They might improve their skills in English by practice to communicate in English frequently, not only at school but wherever they are. In addition, they could also have an extra course on English subject outside the school. Finally, they had to grow their interest in wider aspects of English, including writing.

\section{CONCLUSION}

The researcher has summarized some conclusions towards the research objectives. For the first hypothesis, the Alternative Hypothesis $\left(\mathrm{H}_{1}\right)$ rejected, and the Null Hypothesis $\left(\mathrm{H}_{0}\right)$ is accepted because the coefficient of T-test for regular verb is less than the T-table. Therefore, this proved that there is no influence of Regular Verb Understanding towards Narrative Writing Skills by 11th grade Students of SMA 
Maitreyawira Batam in Academic Year 2012/2013. Then, for the second hypothesis, the researcher found that the coefficient of T-test for irregular verb greater than the T-table. Therefore, $\mathrm{H}_{1}$ is accepted rather than $\mathrm{H}_{0}$. It can be concluded that there is influence of Irregular Verb Understanding towards Narrative Writing Skills by 11th grade Students of SMA Maitreyawira Batam in Academic Year 2012/2013. Furthermore, in the third hypothesis, The F-Test coefficient was greater than the Ftable. This gave a proof that the Null Hypothesis is rejected and the Alternative Hypothesis accepted. It reflected a finding that there is influence of Simple Past Tense Understanding towards Narrative Writing Skills by 11th grade Students of SMA Maitreyawira Batam in Academic Year 2012/2013.

In addition, through the interpretation of the $\mathrm{R}$ square $\left(\mathrm{R}^{2}\right)$ of both regular and irregular verb towards narrative writing skills i.e. $84.1 \%$. It gave important information that even though, there should be another aspects influence the dependent variables, but simple past tense understanding had dominant influences towards narrative writing skills. Afterwards, it also can be concluded that the better simple past tense of student's had, the more she or he can practice the writing skills applied in narrative text. Notwithstanding the conclusion of this research which was only applied to the specific population $\left(11^{\text {th }}\right.$ Grade Students of SMA Maitreyawira Batam) in specific time of Academic Year 2012/1013, overall, this research can give a better conviction to the language learner that the understanding of grammar will help in constructing well-form language as well as in writing (Hewings \& Hewings, 2005: 12). 


\section{REFERENCES}

Cohen, Louis [et al]. 2007. Research Methods in Education. Routledge. New York

Edge, Julian. (1999). Essential of English

Language Teaching. Longman: UK.

Hewings, Ann \& Hewings, Martin. (2005). Grammar and Context. Routledge. UK.

Huddleston, Rodney \& Pullum, Geoffrey K. (2007). A Student's Introduction to English Grammar. Cambridge University Press. New York.

Jackson, Sherri L. (2011). Research Methods: A Modular Approach. Wadsworth. USA.

Jarvie, Gordon. (2007). Bloomsbury Grammar Guide Second Edition. A \& C Black Publishers Ltd. UK.

Litosseliti, Lia. (2010). Research Methods in Linguistics. Continuum International Publishing. UK.

Madsen, Harold S. (1983). Techniques in Testing. Oxford University Press. USA

Min, Young-Kyung. (2012). ESL: Coherence and Cohesion. Accessed on 09 Dec 2012. Available at: http://www.uwb.edu/wacc/resources/e slhandbook/ coherence

O'Graddy, William, [et.al]. (1997). Contemporary Linguistics. Longman: UK.

Richards, Jack C. and Schmidt, Richard. (2010). Longman Dictionary of Language Teaching and Applied Linguistics: Fourth Edition. Pearson Education Limited. UK. 
Rumengan, Jeremy.(2010). Metode Penelitian dengan SPSS. Uniba Press. Batam.

Sahai, Hardeo \& Khursid, Anwer. (2001). Pocket Dictionary of Statistics. McGraw-Hill. USA.

Sarosdy, Judit [et al]. (2006). Applied Linguistics I for BA Students in English. Bolcsezs Kozorcium. Hungary.

SIL. (2009) What are Writing Skills? Accessed on 12 Dec 2012. Available at: http://www.sil.org/lingualinks/literacy Ireferencematerials/glossaryofliteracy termswhatarewritingskills.htm

Sudarwati, Th. M \& Eudia Grace. (2007). Look Ahead 2: An English Course. Erlangga. Indonesia.

Tim Gitamedia Press. (2006). Serious English for Serious Student. Gitamedia Press. Surabaya.

University of Victoria. (2008). Simple Past: Regular Verb. Accessed on 18 Nov 2012. Available at:

http://web2.uvcs.uvic.ca/courses/elc/st udyzone/330/grammar/pasted.htm

Vagias, Wade M. (2006). Likert-type Scale Response Anchors. Accessed on 18 Dec 2012. Available at: www.clemson.edu/centersinstitutes/tourism/documents/samplescales.pdf

Wibowo, Agung Edy. (2012). Aplikasi Praktis SPSS Dalam Penelitian. Gava Media. Yogyakarta. 